\title{
UNIQUE SILVER PENDANT FROM TATCE, KOLÍN DISTRICT, IN THE CONTEXT OF THE OLDEST EVIDENCE OF THE CHRISTIANISATION OF BOHEMIA ${ }^{1}$
}

\author{
N A ĎA P R F A N T O V́́
}

\begin{abstract}
The unique round silver pendant with the motif of either an angel, an orant or a saint most probably comes from the polycultural settlement in the cadastre of Tatce, Kolín distr., in the fertile Elbe River region in central Bohemia. It was found in 2012. The pendant can be unequivocally interpreted as a Christian protective amulet. The find broadens the range of items connected to the earliest Christianity in Bohemia during the $2^{\text {nd }}$ half of $9^{\text {th }}-11^{\text {th }} c$.
\end{abstract}

Keywords: Bohemia, Early Middle Ages, Christianity, silver pendant, jewellery.

\section{INTRODUCTION}

The village of Tatce is located to the east of Prague in the Český Brod district in the fertile Elbe River region. A few years ago, an amateur archaeologist found an interesting pendant in Tatce (the pendant was found in 2012; Fig. 1). While the precise location of the find is not known, ${ }^{2}$ it can be localised to the southern part of the cadastre to the south and the west of the Milčický Stream and southeast of the 'Kouřimská' road running to Tatce, i.e. southeast of the site in 'V Dolních Čtverých'. It is likely a new site with finds from the Roman Period and the Early Middle Ages (Fig. 1). We know other metal finds of Merovingian (bronze belt fitting with a loop) and Early Carolingian types (bronze strap-slide, probably from a spur set) and even Late Avar period types from the Tatce cadastre, specifically from this new site. We cannot rule out that all these finds could originate from the same settlement. All finds were found with the help of a metal detector.

The cadastre of the municipality lies $2-3 \mathrm{~km}$ northeast of the Radim Hillfort (it is from $9^{\text {th }}$ c., also with late Avar Period decorations) at about 190-200 m a.s.l. The Milčický Stream runs through the area and is fed by the Jezírkový Stream. So far, we only know two sites from the area. The first one is a multicultural and repeatedly settled locality to the south of the village on the small 'Ve Čtverých' hill, where the National Museum and the Poděbrady
Regional Museum conducted excavations (J. Hartl, M. Slabina, J. Justová) related to the construction of an oil pipeline (Justová 1965). They documented features from different periods in the west-east direction in a section one kilometre in length. A sunken feature was found in this strip of land with pottery of the Prague type (Zeman 1976, 161), which could be dated to the end of $6^{\text {th }} c$. and the $7^{\text {th }} \mathrm{c}$. However, its exact position in the framework of the whole line is not certain. The second site lies within the built-up area. It was discovered during small-scale excavations headed by Z. Beneš in 2017, which were conducted due to the reconstruction of the first school and kindergarten in Ke hřišti Street (Beneš/Chlup 2018; oral communication). Early medieval features were found but unfortunately weren't fully excavated, only sampled.

\section{Description of the pendant}

The silver pendant is round and decorated on both sides. It had an eyelet, but that has broken off. The reverse side is decorated with a border consisting of dense relief ribbing (or by short incised lines) and divided by a thin raised cross into four fields. One raised globular relief is found in every field. The obverse is decorated by the relief of a schematic figure with a disproportionately large head with a nose suggested in relief, short incised lines for eyes and

\footnotetext{
1 This paper was written with the support of project no. 218-00477S GA ČR, Between Avar and Carolingian Empire. Nodes of the distant contacts in Bohemia of the $8^{\text {th }}$ and the $9^{\text {th }} \mathrm{c}$.

2 The finds were properly located, but, unfortunately, the data were not handed over in time and were lost with the destruction of finder's PC. E. Droberjar also has a not very precise localisation (University of Hradec Králové; I thank him for this information). Despite this, I would like to express my sincere gratitude to the finder for the opportunity to publish these finds.
} 


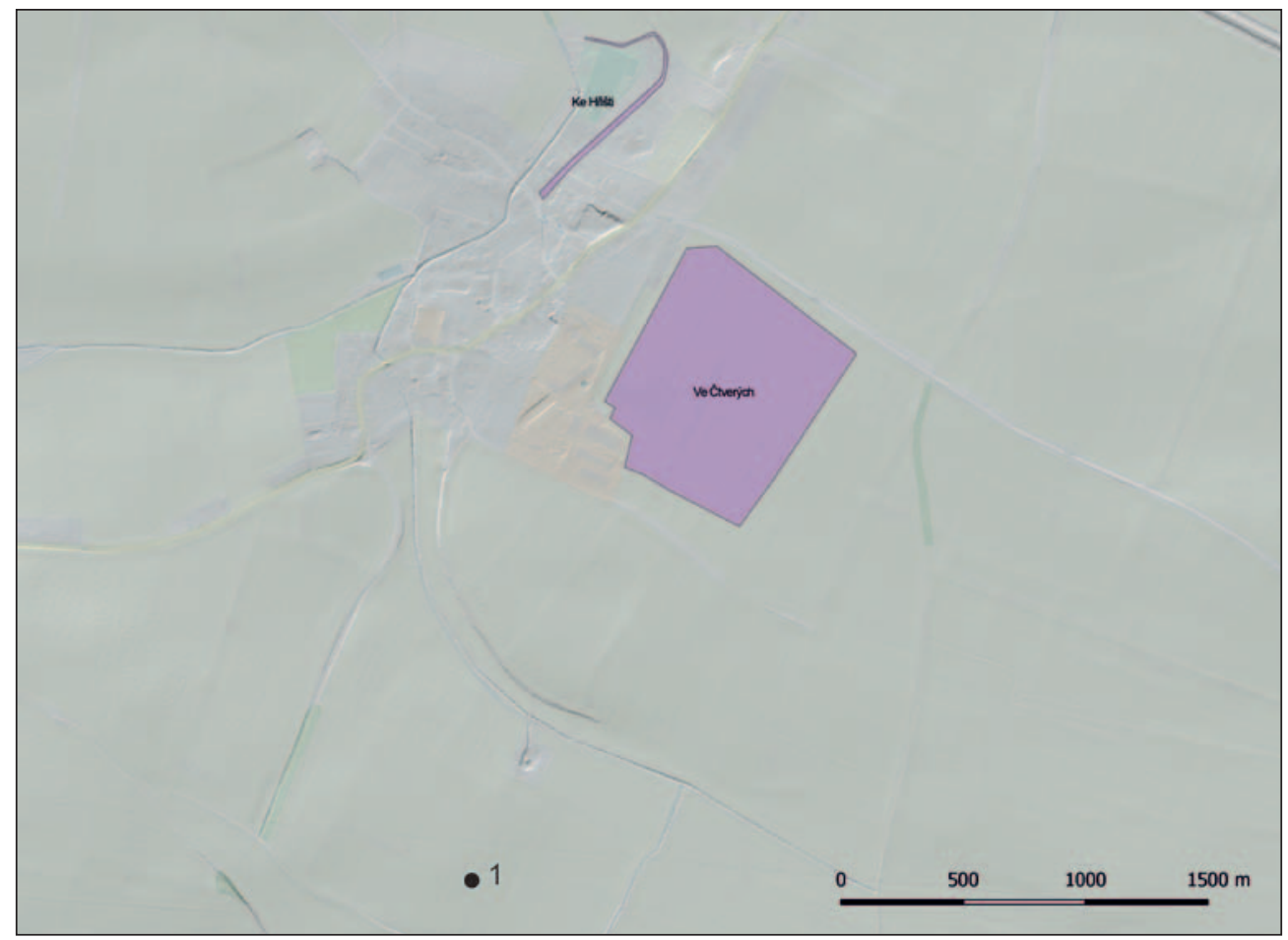

Fig. 1. Tatce, Kolín distr. Early medieval sites, no. 1 is the area in which the pendant was found; purple: Excavations with EM features (graphic by K. Levá).

a horizontal incised line in place of a mouth. The body is made up of a simple triangle without a top. From the upper part of the body run two 'stylised twigs' which seem to symbolise arms or wings: the right one has five points, two of them are paired, whereas the left side has only four tips that all radiate from one point. However, five points wouldn't fit into the designated area (this was probably caused by the inexperience of the craftsman - it needn't have been intentional). The border consists of hallmarked triangles, and the resulting impression is a bit more delicate than that of the reverse. The diameter is $19.2 \mathrm{~mm}$ without the eyelet (Fig. 2: 1). The find is dated from the second half of the $9^{\text {th }} \mathrm{c}$. to the $11^{\text {th }} \mathrm{c}$.

\section{ANALYSIS AND DATING}

The interpretation of the motif on the obverse of the pendant is very important for its categorisation. It could either be an angel - if we read the 'stylised twigs' as wings - or, not very likely, an orant (but held a bit lower than is typical) if we see them as hands; this would be supported by the five tips, fingers, on the right hand. Both variants indicate the probability of an already Christian motif, even if not yet fully rendered. Therefore, we will first try to categorise the pendant as a whole. Although we do not have a precise analogy, there are a few finds similar to the reverse. We can see them in two Romanian pendants from Obîrşia/Obarşia that are dated by O. Toropu and O. Stoica to the $8^{\text {th }} \mathrm{c}$. and by D. Teodor also to the beginning of the $9^{\text {th }}$ c. (Teodor 1981, 68, fig. 20: 5, 6; Toropu/Stoica 1972). Both pendants have similar borders and one of them is divided by a cross into four fields; the second also has a cross but is interrupted in the middle by a half-globular relief and has another four such reliefs in positions similar to the globular decorations on our pendant. According to D. Teodor, the pendants from Romania are most likely of Byzantine origin or type (more probably) and, as far as craftsmanship is concerned, they are less demanding than ours. In the literature, analogies to them are mentioned from two other sites in Romania (Bacan: Zaharia 1967, without depiction; Păcuiul lui Soare: Atanasov 2019, 91, fig. 18; in this case from the first half of the $10^{\text {th }} \mathrm{c}$.). ${ }^{3}$ A lead circular pendant from grave 31 at the burial grounds of Aporka-Ürböpuszta is a bit older (mid-7 ${ }^{\text {th }}$ c., Avar Khaganate period) and Byzantine or more likely made according to a Byzantine model. The decorative field itself is bordered by ring relief and divided by a cross into four fields. Every field has

\footnotetext{
3 Is it a late Roman-Byzantine fortress, a castellum? In the case of Păcuiul lui Soare.
} 


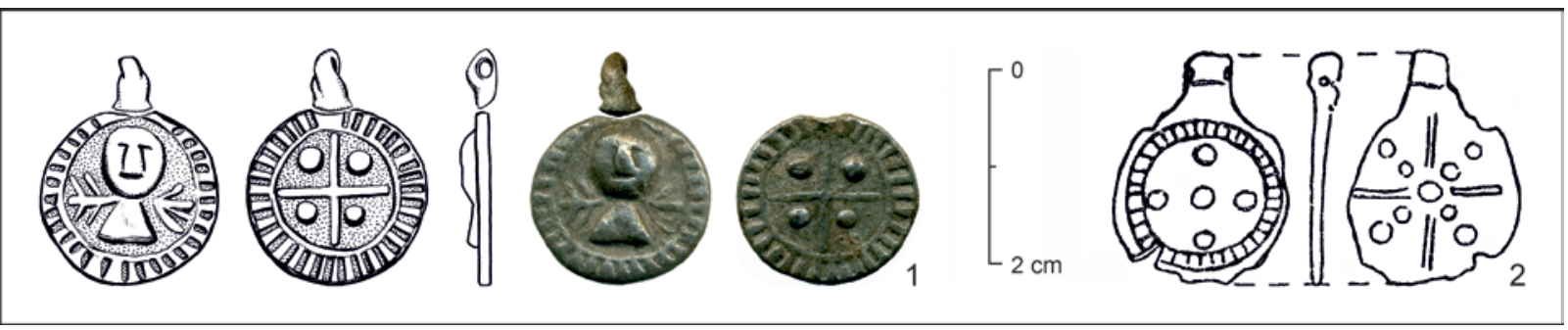

Fig. 2. 1 - silver pendant from Tatce, Czech Republic; 2 - pendant from Obîrşia ${ }_{\llcorner}$Romania (1 - photo and drawing by L. Raslová, ARUP AV ČR, v. v. i.; 2 - after Teodor 1981).

a half-globular protrusion (Garam 2001, pl. 14: 2). There are also other protrusions on the outside like a decorative border. The pendant was found in a grave context with blue beads and a vessel. ${ }^{4}$ The circular reverse of the medallion from Aporka could have its forerunner unequivocally connected with Christianity - one of the variants of circular fibulae with a 'cross motif' (Müller-Wille 2005, 457, fig. $28: 13,17 ; 28: 14$; two pieces of this type of fibula were found relatively close to the Elbe River and thus to the German-Bohemian border). ${ }^{5}$

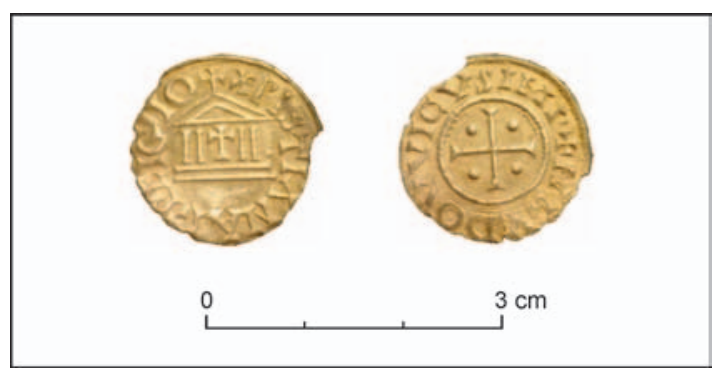

Fig. 3. Olšovice, Prachatice distr. Denarius of Louis the Pious (814-840) found in the wood near the forest road west of the village, probably Paris mint. Diam. $19.4 \mathrm{~mm}$ (unpublished; photo by N. Profantová).

How about the figure motif? The triangular body reminds us of the stylised garment of an orant on the reverse of the strap-end from Mikulčice, grave 390 from the three-aisled basilica (Poulik 1975, pl. 48; colour photo 3: lower middle). The obverse of this fitting is decorated with filigree and folded ribbon; its crownpiece consists of glass inlay and engraved gem/intaglio. If we interpret the shapes next to the body of the figure from Tatce as wings (which is the more probable variant), we have to mention the stylisations of angels on the gilded circular plaques from the Bojná hoard in western Slovakia dated to the $9^{\text {th }} \mathrm{c}$. and published by our celebrant (Fig. 4; Pieta/Ruttkay 2006, F22-F24; F28). The plaques together constituted one symbolic whole, yet not all of them withstood the test of time. They could have been made under the influence of the Langobards as early as in the last third of the $8^{\text {th }} \mathrm{c}$. or the turn of the $9^{\text {th }}$ c. (Štefanovičová 2011; Turčan 2011, fig. 1; 2: 1), after which they remained in circulation for a long time as important valuables. The wings from Bojná are in some cases stylised as relief lines radiating from a thicker line or as trefoils coming out of the arms. Either way, they are evidence of the use of figures with Christian motifs and even inscriptions in the Great Moravia period (the latest references to the plaques from Bojná and their iconography: Csütörtöky 2015). Archangel Raphael from plaque number 5 from Bojná is depicted only with wings (without arms) and it would be easy to further simplify them to the form known to us from the Tatce medallion (Csütörtöky 2015, pl. I: 5). Pre-Romanesque relief comes from Venice, where there is also only a simple triangular body with an indicated belt - a stone relief but the same stylisation, which was apparently widespread (Milošević 2013, fig. 38).

On a small silver target from München-Giesing, grave 164, the figure has disproportionately elongated fingers, which is the second option for explaining these shapes (cf. depiction in Furtmayr 2017, 99, pl. 26: 4; 41; Poulík 1975, pl. 48: 1). Arms and wings could

\footnotetext{
4 On the contrary, I have not registered any similar pendants from Croatia.

5 The division into a cross with four points also appears on later Regensburg denarii with a Czech origin from the end of the $10^{\text {th }}$ c. (cf. Petrán 1998, fig. p. 62), however it does appear earlier in the West on coins of Louis the Pious, e.g. on the revers of a chapel-type denarius from Olšovice in south Bohemia (Prachatice distr.) - these coin therefore start appearing as early as in the first half of $9^{\text {th }}$ C., specifically after the year 822/23 (Fig. 3). If these old coins influenced the appearance of the decoration of the pendant, it could mean it is Bavarian in origin. This type, probably from a Paris mint, was not found in the hoard from Jedomělice, Kladno distr. In Bohemia, it is known only from the Olšovice find (Profantová/Videman/Štěpančík, in press).
} 


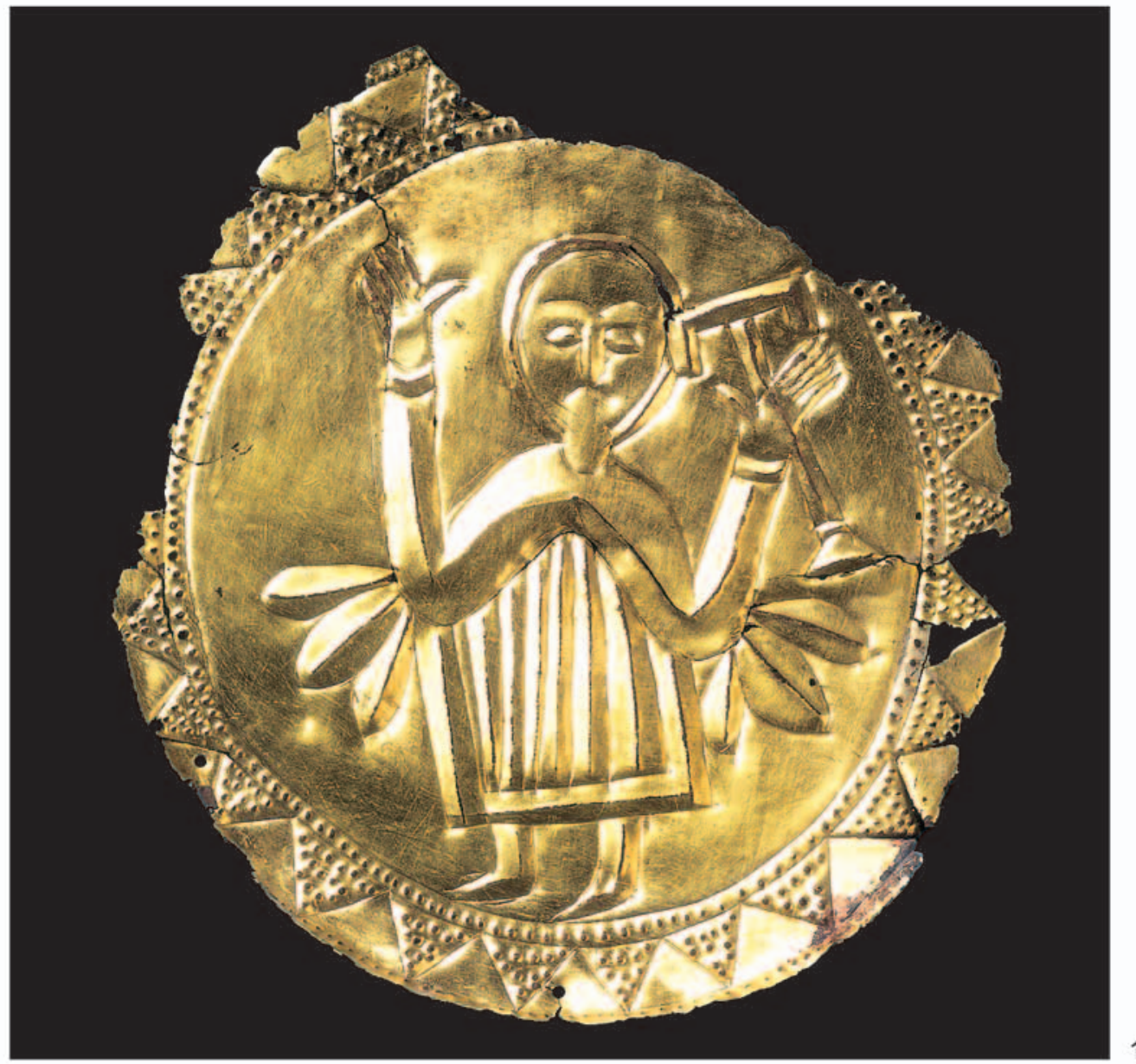

0 $5 \mathrm{~cm}$
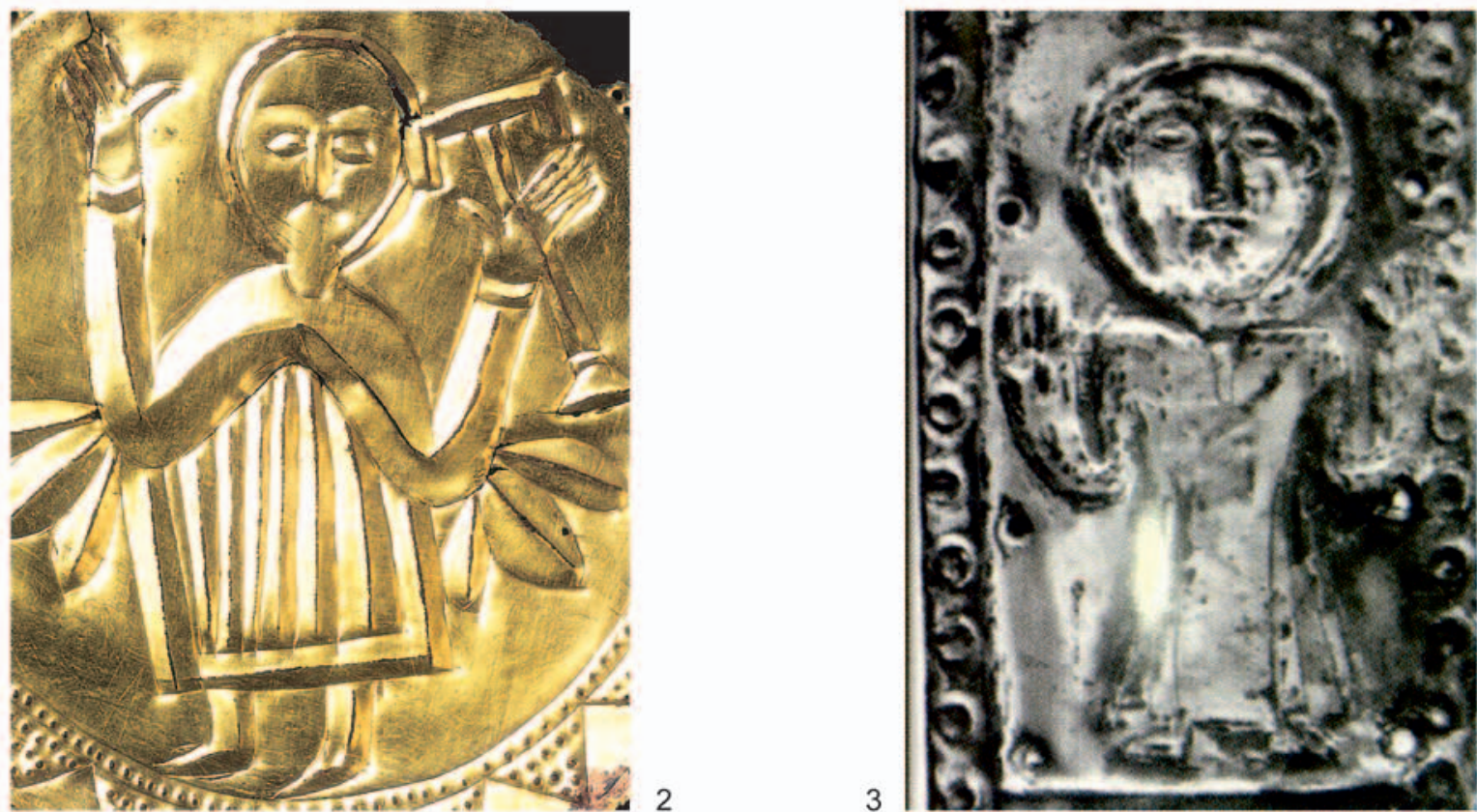

Fig. 4. 1, 2 - gilded plaque with the depiction of an angel from Bojná, Slovakia; 3 - orant from Dörflkirche in Austria with a similarly disproportionately large head (Csütörtöky 2015, pl. II). 
have merged for the craftsman into one structure. The grave is dated to the $7^{\text {th }}$ and the beginning of the $8^{\text {th }} \mathrm{c}$. (earring with one sheet globe).

The stone stele from Leutesdorf in the Rhineland from the $7^{\text {th }} \mathrm{c}$. features the head of a simple stylised person - again with two carved lines for eyes and other carved lines for the nose and mouth, with a triangle as a body and also legs (Roth 1986, pl. 79: b). A simple half-figure with round head and hands with stressed-out fingers is also depicted on the upper part of a reliquary from the end of the $7^{\text {th }}$ c. from Ennabeuren (Quast 2012; Scholkmann 1998). From Merovingian art, we should recall another simple portrayal on metal - the reliquary of St. Mummolin of Saint Benoît-sur-Loire from the $7^{\text {th }}$ c. (cf. Dąbrowska 2003, fig. 5; Lantier 1969, 107, fig. 190; Quast 2012, fig. 23: 4). The middle part has a line of figures with distinctively disproportionate heads and schematic bodies in robes without legs - in only a slightly more exacting rendition than the triangular schematisation on our pendant. The eyes look like two short lines and the mouth is one line. Also, a very important element is the artistic elongation of the linking of schematic figures and a geometric ornament (Lantier 1969, 102-109). ${ }^{6}$ Unartful figurines of Christ and an angel(?) in a long tunic that goes all the way down to the ankles, with wings and arms in the gesture of adoration and with nails in his hands(?) are depicted on a reliquary or portable altar from Werden (Essen-Werden) from the $8^{\text {th }}$ c. (Schulze-Dörrlamm 2002). The depiction clearly shows how the Christian and Pagan ideas mixed in the use of stylistic uniformity (animals near Christ's feet and on one whole side of the reliquary and so on; there exist various interpretations of theses syncretic ideas: cf. Milošević 2013, 165, 166). From the depictions from the $8^{\text {th }} \mathrm{c}$., an important role is played by one of the two angels surrounding the cross found on a silver brooch from female grave 208 from Kirchheim/Ries. The Angels have stylised arms/wings as five slanting lines (Fig. 5; SchulzeDörrlamm 2002, fig. 38). Knowledge of similar images made it possible for our unartful wing stylisation to come into being. It is clear that the likeness of the pendant from Tatce could have been influenced by south-eastern as well as western artwork/originals. These artworks had been absorbed in Moravia during the $9^{\text {th }} \mathrm{c}$. and also in Bohemia in this time and in the first half of the $10^{\text {th }} \mathrm{c}$.

We know another relief head (of better quality) from a Byzantine pectoral cross (Encolpion) from Kouřim (Profantová/Stolz 2007, fig. 2) from the second half of the $10^{\text {th }}$ or $11^{\text {th }}$ c., which we also consider a Byzantine product. The relationship

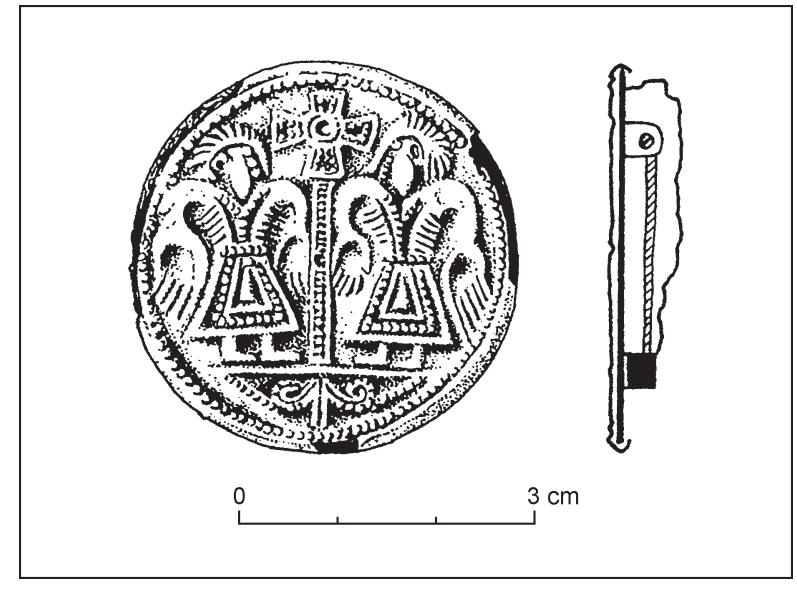

Fig 5. Kirchheim/Ries. Silver brooch from grave 238, first third of the $8^{\text {th }}$ c. (Schulze-Dörrlamm 2003, fig. 38).

to Byzantium in this case is also supported by an inscription in Greek. As is evident, the image is too simple for an unequivocal localisation of its production location. We look for the roots of this motif in the barbarised Byzantine milieu or more likely in places where the Byzantine and Western conceptions were intermixing. This does not disprove the origin of the pendant at the main Moravian centres and its movement further into central Bohemia. We cannot rule out the possibility of its production in Bohemia according to a foreign model if it is from the $10^{\text {th }} \mathrm{c}$. or later. We have new evidence of the production of silver from ore in a few locations in Prague from the $10^{\text {th }} \mathrm{c}$. (crucibles and sherds with traces of metal; Zavřel/Čiháková 2019).

\section{CONCLUSION AND HISTORICAL CONTEXT}

The unique silver pendant with the figure of angel or saint(?), but without a nimbus, from Tatce is a slightly barbarised Byzantine 'provincial' product or its imitation. It could have originated in the Balkans, northern Italy or at a Moravian centre. We cannot fully disprove the south Bavarian possibility. We can unequivocally interpret it as a Christian protective amulet.

The most difficult task is the dating of the pendant. Similar pendants appear from the middle of the $7^{\text {th }} \mathrm{c}$. to at least the end of the $10^{\text {th }}$ and possibly also in the $11^{\text {th }} \mathrm{c}$. It all depends on the context of the find and the region in which it was made.

In this situation, we will help ourselves with the historical context. The baptism of fourteen

6 Similar simple figures also appear in Irish-Scottish art. 
Czech dukes in January of the year 845 is mentioned in the Annales Fuldenses (845 AD), though its influence on the baptised members of the elite is unclear. ${ }^{7}$

To date, we could not link baptism with the building of churches. Only two unique finds of decorations with the Christian cross can be tied to it - a gilded fitting with a central motif of a carved cross in the style of Tassilo chalice from Černovice Hillfort in northwest Bohemia (Profantová 2021, 45, 46 , with fig.) and a simple bronze equilateral cross decorated with stamped circles from Levý Hradec and its vicinity, which most likely comes from Bavaria and was made in the second half of the $8^{\text {th }}$ or the $9^{\text {th }}$ c. (Profantová 2014). Bohemian Duke Bořivoj [Borzivogius, in some cases written in Latin as Gorziwei († 889)], the first historically documented Přemyslid, accepted baptism again and not fully willingly at the Moravian court of Duke Svatopluk between years the 882 and 884 . At that time, he safely built at least two churches after his return in Levý Hradec and later at Prague castle (Legenda Christiani, end of $10^{\text {th }}$ c.: Ludvíkovsky 1978, 18-21; the small Church of the Virgin Mary was archaeologically excavated by I. Borkovský: e.g. Frolik 2018). ${ }^{8}$

Christianisation did not go smoothly, not even back then, as Strojmír's uprising mentioned in Legenda Christiani demonstrates (Ludvíkovský 1978). Still, the situation after 884 AD was more favourable to the spreading of Christian symbols, at least among the members of the elite. The symbols of crosses as main and side motifs as well as Dextera Domini and the less unequivocally Christian birds - in some cases probably peacocks, ${ }^{9}$ also appear on spherical buttons (gombíky) of Bohemian provenance (Prague-Lumbe Garden and the Royal Gardens, less unequivocally Kouřim: cf. Frolík/Smetánka 2014; Šlle 1966), decorative panelling from antler from the end of the $9^{\text {th }} \mathrm{c}$. and the beginning of the $10^{\text {th }} \mathrm{c}$. (Budeč: cf. Boháčová/Profantová 2014), and now we even know of them from an imported Carolingian fitting with a motif of birds (peacocks) facing each other from the end of the $9^{\text {th }} \mathrm{c}$. and the beginning of the $10^{\text {th }} \mathrm{c}$. (unpublished).

The aforementioned historical connections narrow down the long interval of the possible appearance of the pendant in Bohemia, specifically Tatce. It most likely appeared in Bohemia in the period from the last third of the $9^{\text {th }} \mathrm{c}$. to the end of the $11^{\text {th }} \mathrm{c}$; however, the $10^{\text {th }} \mathrm{c}$. appears most likely. ${ }^{10}$ It could have reached us with Great Moravian ornaments (even if we have no knowledge thus far of exact analogies) as well as separately. If it did come from the latter part of the interval, it could also have been made in Bohemia, since Prague ran a jewellery workshop of high quality (FrolikováKaliszová 2020; Profantová 2013; Profantová a kol. 2015, 85;), the oldest crucibles and pottery shards with traces of silver come from the Prague-Malá Strana suburb in addition to other sources from the excavations of J. Čiháková in the area of the stone Rotunda of St. Wenceslaus. These come from the first third of the $10^{\text {th }} \mathrm{c}$. and it has also been proven by microanalyses that it was not just working with 'silver scraps' but the production of silver directly from ore (Zavřel/Čiháková 2019; Zavřel/ČihákoválJežek 2019).

The context of the still largely unknown settlement does not really help us make a more accurate dating of the pendant; the other find of an Early Carolingian strap-slide indicates long-distance connections at the latest at the turn of the $8^{\text {th }} / 9^{\text {th }} \mathrm{c}$.

\footnotetext{
7 It could have been primarily a political move. Christ could have been added to the altars of Pagan gods within the framework of the syncretic ideas of some nobles without anyone having an issue with it. This happened in northern Europe, for example in Szczecin, where a pagan altar was added to the Christian altar (Sommer 2020). The duke buried in the middle of the $9^{\text {th }} \mathrm{C}$. in Kolín could have belonged among the baptised (Košta/Lutovský 2014; Profantová 2011; 2021).

8 For an in-depth summary of written sources and archaeology in the $10^{\text {th }} \mathrm{c}$. in English, see Profantová 2009.

9 We can recognise a 'peacock tuft'/'fan-like crest' on a bird's head in the case of grave 99 in Prague-Lumbe Garden.

${ }^{10}$ At this time, Prague was an important trade centre (in the E-W direction) and, at the same time, Christianisation intensified through central sites.
} 


\section{BIBLIOGRAPHY}

Atanasov 2019 - G. Atanasov: On the Initial Date of the Medieval Lower Danube Fortress of Păcuiul lui Soare and Its Harbour. Archaeologia Bulgarica 23/1, 2019, 77-106.

Beně̌/Chlup 2018 - Z. Beneš/T. Chlup: Tatce, okr. Kolín. In: Lutovský a kol. 2018, 770.

Boháčová/Profantová 2014 - I. Boháčová/N. Profantová: Bohemia and Great Moravia: archaeological evidence. In: P. Kouřil (ed.): Great Moravia and the beginnings of Christianity. Brno 2014, 143-154.

Csütörtöky 2015 - J. Csütörtöky: Nové poznatky k ikonografii a ikonológii pozlátených medených plakiet z Bojnej a hypotetická rekonštrukcia ich aplikácie. In: K. Pieta/Z. Robak (eds.): Bojná 2. Nové výsledky výskumov včasnostredovekých hradisk. Archaeologica Slovaca Monographiae. Fontes 20. Nitra 2015, 115-138.

Dąbrowska 2003 - E. Dąbrowska: Zagadkowy grób Pielgrzyma z Grzebska kolo Mławy - głos w dyskusji. In: M. Dulinicz (red.): Stowiane i ich sasiedzi we wczesnym średniowieczu. Lublin -Warszawa 2003, 281-287.

Frolík 2018 - J. Frolík: Pohřebiště u kostela P. Marie. In: I. Štefan/M. Wihoda (eds.): Kostel Panny Marie na Pražském hradě. Dialog nad počátky křst’anstuí $v$ Čechách. Prameny české historie 3. Praha 2018, 64-99.

Frolik/Smetánka 2014 - J. Frolík/Z. Smetánka: Castrum Pragense. Pohřebištěv Lumbeho zahradě na Pražském hradě. Castrum Pragense 12, díl I. Katalog. Praha 2014.

Frolíková-Kaliszová 2020 - D. Frolíková-Kaliszová: Nový př́spěvek ke šperkařské produkci pražské dílny. Archaeologia historica 45, 2020, 45-65.

DOI: https://doi.org/10.5817/AH2020-1-2

Furtmayr 2017 - H. Furtmayr: München Giesing. Ein frühmittelalterliches Gräberfeld vor der Stadt. Abhandlungen und Bestandskataloge der Archäologischen Staatssammlung digital. Band 1. München 2017. Online available at: https://langzeitarchivierung.bib-bvb.de/delivery/DeliveryManagerServlet?dps_pid=IE7724192\&change_lng=

Garam 2001 - É. Garam: Funde byzantinischen Herkunft in der Awarenzeit vom Ende des 6. bis zum Ende des 7. Jahrhunderts. Budapest 2001.

Justová 1965 - J. Justová: Štítarské sídliště u Tatců, o. Nymburk. Archeologické rozhledy 17, 1965, 38-42.

Košta/Lutovský 2014 - J. Košta/M. Lutovský: Raně středověký knižecí hrob z Kolina. Fontes Archaeologici Pragenses 41/1. Praha 2014.

Lantier 1969 - R. Lantier: Vpády barbarů a raný středověk. In: R. Huyghe (ed.) Encyklopedie umění středověku. Světové dějiny 34. Umění a lidstvo. Praha 1969, 102-109.
Ludvíkovský 1978 - J. Ludvíkovský: Kristiánova legenda: Život a umučení sv. Václava a sv. Ludmily, báby jeho. Praha 1978.

Lutovský a kol. 2018 - M. Lutovský a kol.: Terénní výzkumy Ústavu archeologické památkové péče středních Čech v r. 2017. Archeologie ve středních Čechách 22, 2018, 745-774.

Milošević 2013 - A. Milošević: Tragovi starih vjerovanja u krśćanstvu ranog srednjeg vijeka. Studia mediterranea archaeologica 6. Dubrovnik Split 2013.

Müller-Wille 2005 - M. Müller-Wille: The Cross Goes North. Carolingian Times between Rhine and Elbe. In: M. Carver (ed.): The Cross Goes North. Processes of conversion in Northern Europe. AD 300-1300. Woodbridge - Rochester 2005, $443-462$.

Petráň 1998 -Z. Petráň: Proní české mince. Praha 1998. Pieta/Ruttkay 2007 - K. Pieta/A. Ruttkay: Bojná. Mocenské a christianizačné centrum Nitranského kniežatstva. In: K. Pieta/A. Ruttkay/M. Ruttkay (eds.): Bojná. Hospodárské a politické centrum Nitranského kniežatstva. Archaeologica Slovaca Monographiae. Studia 9. Nitra 2007, 21-69.

Poulík 1975 -J. Poulík: Mikulčice. Sídlo a pernost knižat velkomoravských. Praha 1975.

Profantová 2009 - N. Profantová: Archeology and written sources on eighth- to tenth-century Bohemia. Early Medieval Europe 17, 2009, 286-310.

Profantová 2011 - N. Profantová: Karolinské importy a jejich napodobování v Čechách, případně na Moravě (konec. 8.-10. století). In: Turčan zost. 2011, 71-104.

Profantová 2013 - N. Profantová: Ke změnám ve vývoji hmotné kultury 10 . století. Archaelogia historica 38, 2013, 27-44.

Profantová 2014 - N. Profantová: I. 8. Bronzový litý křížek, In: D. Foltýn/J. Klípa/P. Mašková/P. Sommer/V. Vlnas (eds.): Otevři zahradu rajskou. Benediktini v srdci Evropy 800-1300. Praha 2014, 27.

Profantová a kol. 2015 - N. Profantová a kolektiv: Klecany. Raně středověká pohřebiště I. Praha 2015.

Profantová 2021 - N. Profantová: Čechy v době narození kněžny Ludmily. In: J. Izdný (red.): Ludmila. Kněžna a světice. Praha 2021, 29-58.

Profantová/Stolz 2007 - N. Profantová/D. Stolz: Nový nález relikviářového kř́̌žku z Kouřimi. In: E. Doležalová/R. Šimůnek (eds.): Od knižat ke králưm. Sborník u př́ležitosti 60. narozenin J. Žemličky. Praha 2007, 124-130, 604.

Profantová/Videman/Štěpančík, in press - N. Profantová/J. Videman/Z. Stěpančík: Dálkové kontakty Netolicka v raném středověku: svědectví mincí a ozdob. Numismatické listy, in press. 
Quast 2012 - D. Quast: Das merowingerzeitliche Reliquienkästchen aus Ennabeuren. Eine Studie zu den frühmittelalterlichen Reisereliquiaren und Chrismalia. Kataloge vor- und frühgeschichtlicher Altertümer. Band 43. Mainz 2012.

Roth 1986 - H. Roth: Kunst und Handwerk im frühen Mittelalter. Stuttgart 1986.

Scholkmann 1998 - B. Scholkmann: Die frühen Kirchen. In: S. Lorenz/B. Scholkmann: Die Alemannen und das Christentum. Zeugnisse eines kulturellen Umbruchs. Schriften zur südwestdeutschen Landeskunde 48. Stuttgart 1998, 455-464.

Schulze-Dörrlamm 2002 - M. Schulze-Dörrlamm: Der rekonstruierte Beinkasten von Essen-Werden. Reliquiar und Mutmasslicher Tragaltar des Hl. Liudger aus dem späten 8. Jahrhundert. Jahrbuch des Römisch-Germanischen Zentralmuseum Mainz 49, 2002, 281-361.

DOI: https://doi.org/10.11588/jrgzm.2002.0.23285

Šolle 1966 - M. Šolle: Stará Kouřim a projevy velkomoravské hmotné kultury v Čechách. Monumenta archaeologica 15. Praha 1966.

Sommer 2020 - P. Sommer: Christianizace, pokřestanění, christianisovati, obraceti na křestanství. In: I. Boháčová/P. Sommer (eds.): Raný český stát 10. století. Colloquia mediaevalia Pragensia 21. Praha 2020, 227-246.

Štefanovičová 2011 - T. Štefanovičová: Iroškótská misia a Slovensko. In: Turčan zost. 2011, 117-122.
Teodor 1981 - D. Gh. Teodor: Romanitatea CarpatoDunăreană și Bizanţul in veacurile $V-X I$ e. $n$. Iași 1981.

Toropu/Stoica 1972 - O. Toropu/O. Stoica: La nécropole préféodale d'Obîrşia-Olt (note préliminaire). Dacia n. s. 16, 1972, 163-188.

Turčan 2011 - V. Turčan: Severný Jadran - jeden z možných inšpiračných zdrojov umeleckého remesla stredodunajských Slovanov. In: Turčan zost. 2011, 123-127.

Turčan zost. 2011 - V. Turčan (zost.): Karolínska kultúra a Slovensko. Štúdie. Zborník SNM. Archeológia. Supplementum 4. Bratislava 2011.

Zaharia 1967 - E. Zaharia: Săpăturile de la Dridu. Contribuţie la arheologia şi istoria perioadei de formare a poporului român. Biblioteca de arheologie 12. București 1967.

Zavřel/Čiháková 2019 - J. Zavřel/J. Čiháková: Praha stříbrná. Výsledky analýz raně středověkých archeometalurgických nálezů z Malé Strany. Archeologické rozhledy 71, 2019, 475-528.

Zavřel/Čiháková/Ježek 2019 - J. Zavřel/J. Čiháková/ M. Ježek: Domestic pottery sherds used in non-ferrous metalworking: a study from early medieval Prague. Archaeological and Anthropological Sciences 11, 2019, 5339-5358.

DOI: https://doi.org/10.1007/s12520-019-00865-w

Zeman 1976 - J. Zeman: Nejstarší slovanské osídlení Čech. Památky archeologické 67, 1976, 115-235.

Manuscript accepted 31. 5. 2021

Translated by Daniela Profantová

PhDr. Nad’a Profantová, CSc.

Archeologický ústav AV ČR Praha, v. v. i.

Letenská 4

CZ - 11801 Praha 1

profantova@arup.cas.cz 